\section{Differing Blanketflower Cultivar and Ecotype Responses to Plant Growth Regulators}

\author{
Helen E. Hammond ${ }^{1,5,7}$, Richard K. Schoellhorn ${ }^{2}$, \\ Sandra B. Wilson ${ }^{3,6,8}$, and Jeffrey G. Norcini ${ }^{4,6}$
}

AdDitional index words. Gaillardia pulchella 'Torch Flame', ethephon, uniconazole, growth retardant, native plants, Sumagic, Florel, firewheel

Summary. Two different plant growth regulators were applied to 'Torch Flame' blanketflower (Gaillardia pulchella) and a native blanketflower ecotype to reduce pedicel elongation and final production size. Uniconazole was applied as a spray at 60,120 , and $180 \mathrm{mg} \cdot \mathrm{L}^{-1}$ or as a drench at 6,12 , and $24 \mathrm{mg} \cdot \mathrm{L}^{-1}$ one and two times per plant. Ethephon was applied as a spray at 500 and $1000 \mathrm{mg} \cdot \mathrm{L}^{-1}$ one and two times per plant. When applied as a spray, uniconazole had no effect on torch blanketflower, but when applied as a drench, growth indices were reduced by $12 \%$ to $30 \%$ without delayed flowering. When treated with ethephon spray, torch blanketflower was $\mathbf{1 5 \%}$ to $\mathbf{2 5 \%}$ more compact than untreated controls, but flowering was delayed. The blanketflower ecotype did not respond to uniconazole or Ethephon treatments, regardless of the application rate, number, or method.

$\mathrm{B}$ lanketflower is an herbaceous annual in the Aster family. It is native throughout Florida (Wunderlin and Hansen, 2004) and most of the United States (U.S. Department of Agriculture, 2006), with cultivated varieties grown worldwide. Using blanketflower (Gaillardia pulchella) and common gaillardia ( $G$. aristata) as parents, more than 30 cultivars have been produced that vary in floral attributes, flowering time, vegetative characteristics, cold tolerance, and landscape performance (Schoellhorn, 2004). The ornamental value of blanketflower is further revealed by its use in many state university trial gardens including

Indian River Research and Education Center Journal Series No. R-080702.

We gratefully acknowledge Bob Weidman and Seth Hammond for greenhouse assistance, and Carolyn Bartuska for statistical expertise. We thank Ball FloraPlant for donating unrooted cuttings.

${ }^{1}$ Department of Environmental Horticulture, P.O. Box 110670, Gainesville, FL 32611

${ }^{2}$ Proven Winners, 7421 NW 176th Street, Alachua, FL 32615

${ }^{3}$ Department of Environmental Horticulture, Indian River Research and Education Center, University of Florida-IFAS, 2199 South Rock Road, Fort Pierce, FL 34945

${ }^{4}$ Department of Environmental Horticulture, North Florida Research and Education Center, University of Florida-IFAS, 155 Research Road, Quincy, FL 32351-5677

${ }^{5}$ Graduate Research Assistant.

${ }^{6}$ Associate Professor.

${ }^{7}$ Current address: Faculty Extension Assistant, MD Cooperative Extension, 18330 Keedysville Road, Keedysville, MD 21756.

${ }^{8}$ Corresponding author. E-mail: sbwilson@ifas.ufl.edu.
University of Georgia, Colorado State University, North Carolina State University, Auburn University, Pennsylvania State University, and even in Canada at the University of Guelph. In 2005, The University of Florida "trialed" 23 blanketflower cultivars and ecotypes and found that two of the Florida ecotypes (from Leon and Okaloosa counties) had greater or equal landscape impact than many of the cultivated selections (Danielson, 2005).

Many of the blanketflower cultivars available today can be propagated Although relatively easy to produce, blanketflower is fast growing and can quickly reach a cumbersome size for handling and shipping. Applications of plant growth regulators (PGRs) may help to extend the amount of time these plants can be held before distribution and sale, to improve visual quality, and to facilitate shipping. There are many PGRs available for use on ornamental crops, but their effectiveness is often species or even cultivar specific (Barrett, 2001; by seed in addition to cuttings.
Chamberlayne and Banko, 2003; Hilgers et al., 2005; Keever and Olive, 1994; Kim et al., 1999; Latimer et al., 2006). To our knowledge, no information has been reported for chemical plant growth regulation of blanketflower, with the exception of 'Burgundy' blanketflower (G. $\times$ grandiflora), of which $G$. pulchella is a parent. Thomas et al. (1998) and Latimer et al. (1999) found that PGR response of burgundy blanketflower varied by application rate, application number, and PGR type. We conducted a preliminary study with a blanketflower ecotype (G. pulchella) and a cultivated selection of 'Torch Flame' blanketflower ( $G$. pulchella) to determine how three commercially available PGRs [daminozide (B-Nine; Uniroyal Chemical Co., Middlebury, CT) daminozide/chlormequat chloride (Cycocel; Olympic Horticultural Products Co., Mainland, PA), and paclobutrazol (Bonzi; Syngenta Crop Protection, Inc., Greensboro, NC)] affect plant growth and flowering, and found none of these PGRs to be effective in controlling plant growth (Danielson, 2005). The cultivar Torch Flame is a Ball Selection (Ball FloraPlant, West Chicago) characterized by having heat-tolerant, longlasting blooms with trumpet-shaped ray florets in hues of yellow, red, and orange on well-branched, upright plants. The Florida ecotype has a looser growth habit and fewer ray florets that are horizontally oriented. There is a potential market for local or regional ecotypes in landscape plantings as public awareness and use of native species has become more widespread (Florida Wildflower Advisory Council, 2004; Hammond et al., 2007; Norcini and Aldrich, 2004).

In addition to daminozide, daminozide/chlormequat chloride, and paclobutrazol, two other commonly used chemical growth retardants are uniconazole (Sumagic; Valent USA Corp., Walnut Creek, CA) and

\begin{tabular}{llll}
\hline $\begin{array}{l}\text { Units } \\
\text { To convert U.S. to SI, } \\
\text { multiply by }\end{array}$ & U.S. unit & SI unit & $\begin{array}{l}\text { To convert SI to U.S., } \\
\text { multiply by }\end{array}$ \\
\hline 10 & $\%$ & $\mathrm{~mL} \cdot \mathrm{L}^{-1}$ & 0.1 \\
3.7854 & $\mathrm{gal}$ & $\mathrm{L}$ & 0.2642 \\
28.3495 & $\mathrm{Oz}$ & $\mathrm{g}$ & 0.0353 \\
1 & $\mathrm{ppm}$ & $\mathrm{mg} \cdot \mathrm{L}^{-1}$ & 1 \\
0.1019 & $\mathrm{qt} / 100 \mathrm{ft}^{2}$ & $\mathrm{~L} \cdot \mathrm{m}^{-2}$ & 9.8170 \\
$\left({ }^{\circ} \mathrm{F}-32\right) \div 1.8$ & ${ }^{\circ} \mathrm{F}$ & ${ }^{\circ} \mathrm{C}$ & $\left(1.8 \times{ }^{\circ} \mathrm{C}\right)+32$
\end{tabular}


Ethephon (Florel; Southern Agricultural Insecticides, Palmetto, FL). Similarly to daminozide, uniconazole inhibits the synthesis of gibberellins, but often at a lower concentration and with greater efficacy (Barrett, 2001). Ethephon is an ethylenereleasing compound that has been used to suppress height in some species (Krug et al., 2006; Rademacher, 1991). The objective of the current study was to determine whether uniconazole or ethephon, used at varying rates with one or two applications, can reduce plant size of cultivated and noncultivated forms of blanketflower.

\section{Materials and methods}

Torch blanketflower cuttings (Ball FloraPlant) were rooted in Fafard no. 2 medium (Conrad Fafard, Agawam, MA) in 72-cell trays. Seeds of a Florida blanketflower ecotype were collected from a native population in Crestview, FL (Okaloosa County) and sown in Fafard no. 2 medium in 128-cell trays. Seed trays and cuttings were kept under intermittent mist (10 s every $20 \mathrm{~min}$ ) for $10 \mathrm{~d}$, then moved to a greenhouse, where they were watered with 150 $\mathrm{mg} \cdot \mathrm{L}^{-1} 20 \mathrm{~N}-4.3 \mathrm{P}-16.6 \mathrm{~K}$ liquid fertilizer (20-10-20; The Scotts Co., Marysville, $\mathrm{OH}$ ). Rooted cuttings (3 weeks old) or seedlings ( 8 weeks old) were transplanted into 1 -gal containers filled with Fafard no. 2 medium and manually drip irrigated (until runoff) as needed. Nine plants having 8 to 16 expanded leaves with visible roots at the edge of the substrate were assigned randomly to each treatment. On 11 July 2005 (1 week after transplanting to 1 -gal containers), uniconazole-P was uniformly applied ( 2 qt/ $100 \mathrm{ft}^{2}$ ) with a $\mathrm{CO}_{2}$ sprayer at 60 , 120 , and $180 \mathrm{mg} \cdot \mathrm{L}^{-1}$, or as a drench at 6,12 , and $24 \mathrm{mg} \cdot \mathrm{L}^{-1}$. Ethephon was applied ( $\left.3 \mathrm{qt} / 100 \mathrm{ft}^{2}\right)$ using a $\mathrm{CO}_{2}$ sprayer at 500 and $1000 \mathrm{mg} \cdot \mathrm{L}^{-1}$. A spray adjuvant CapSil (Aquatrols, Cherry Hill, NC) was added to ethephon solutions at $0.5 \mathrm{~mL} \cdot \mathrm{L}^{-1}$. The second uniconazole and ethephon application (for treatments that received two applications) was applied 1 week after the initial treatment. Distilled deionized water was applied as a control and used to make all other solutions.

After 3 weeks, the height and perpendicular width of each plant were measured to obtain a growth index. Height was measured from the soil level to the highest vegetative point. Width was measured first at the widest vegetative point passing through the center of the plant, and a second measurement was taken perpendicular to the first. Growth index was calculated as [ (height + average width)/2]. Visual compactness was assessed on a scale from 1 to 3 points, where 1 point is not compact, 2 points is somewhat compact, and 3 points is highly compact. At 3 weeks, the total number of flowers having at least one fully expanded ray floret was counted for each plant. All but one plant from each block was severed at the crown (soil level), placed into individual paper bags, and oven-dried at $70^{\circ} \mathrm{C}$ for 1 week, after which dry weights were recorded. Flower number of the remaining plants was counted again at 4 weeks. Plants were arranged in a completely randomized block, with three blocks having three replications of each treatment. The study was repeated once with similar results. Values presented are from the first study. Data were subjected to analysis of variance, and main effects of treatments were partitioned into single df (orthogonal contrasts) at $P \leq 0.05$.

\section{Results and discussion}

Uniconazole. Nonsignificant rate $x$ drench number interactions occurred for each measured trait of torch blanketflower plants drenched with uniconazole (Table 1). Uniconazole-drenched plants had significantly lower growth indices and dry weights, with greater compactness than control plants. Increasing the rate linearly decreased the growth index and dry weight of plants. Dry weight was reduced by $16 \%$ to $31 \%$, compared with untreated controls, without significantly affecting flowering (Table 1, Fig. 1). A second drench had no effect on growth, and delayed flowering at 4 weeks. As a spray, uniconazole was ineffective in reducing growth of torch blanketflower (data not presented). Also, regardless of application rate, number, or method (spray or drench), uniconazole did not affect blanketflower ecotype growth (data not presented).

Plant responses to foliar or drench applications of the same PGR often vary as a result of differences in absorption rates and translocation. Unlike ethephon, uniconazole can be applied as a media drench or foliar spray. Because it is xylem transported to the growing points, applications to the leaves do not actively move to other parts of the plant (Whipker et al., 2003). Although foliar sprays of uniconazole did not affect plant growth of blanketflower in our study, Kim et al. (1999) found foliar spays of uniconazole to be more effective in reducing total plant height of bleeding heart (Dicentra spectabilis) than

Table 1. Growth index, dry weight, compactness rating, and flower number of 'Torch Flame' blanketflower drenched with uniconazole $(n=9)$.

\begin{tabular}{|c|c|c|c|c|c|c|}
\hline Rate $\left(\mathrm{mg} \cdot \mathrm{L}^{-1}\right)^{\mathrm{z}}$ & $\begin{array}{l}\text { Drenches } \\
\text { (no.) }\end{array}$ & $\begin{array}{l}\text { Growth } \\
\text { index }^{y}\end{array}$ & $\begin{array}{l}\text { Dry } \\
\text { wt } \\
(g)^{x} \\
\end{array}$ & $\begin{array}{l}\text { Compactness } \\
\text { rating } \\
(1-3 \text { scale })^{\mathrm{w}}\end{array}$ & $\begin{array}{c}\text { Flowers } \\
\text { at } 3 \text { wk } \\
\text { (no.) }\end{array}$ & $\begin{array}{c}\text { Flowers } \\
\text { at } 4 \text { wk } \\
\text { (no.) }\end{array}$ \\
\hline Control & - & 31.8 & 15.4 & 1.0 & 4.7 & 9.5 \\
\hline 6 & 1 & 29.2 & 14.9 & 1.3 & 3.5 & 11.0 \\
\hline 6 & 2 & 26.7 & 12.9 & 1.4 & 3.2 & 5.0 \\
\hline 12 & 1 & 25.8 & 12.4 & 1.4 & 4.3 & 9.5 \\
\hline 12 & 2 & 25.9 & 15.1 & 2.2 & 2.7 & 3.5 \\
\hline 24 & 1 & 21.9 & 10.7 & 2.7 & 3.2 & 5.5 \\
\hline 24 & 2 & 22.5 & 12.4 & 2.4 & 2.3 & 5.0 \\
\hline \multicolumn{7}{|l|}{ Contrasts } \\
\hline Control vs. others & & $* *$ & * & $\star *$ & NS & NS \\
\hline Rate & & $\mathrm{L}^{* *}$ & $\mathrm{~L}^{*}$ & $\mathrm{~L}^{* *}$ & NS & NS \\
\hline Drench no. & & NS & NS & NS & NS & * \\
\hline Rate vs drench no. & & NS & NS & NS & NS & NS \\
\hline \multicolumn{7}{|c|}{ 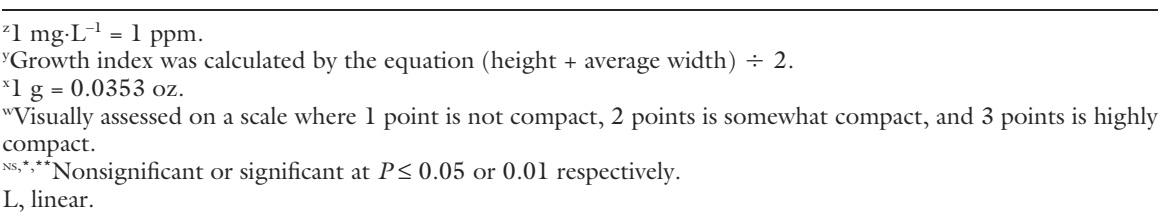 } \\
\hline
\end{tabular}


media drenches. Likewise, Gibson and Whipker (2001) reported that increasing the foliar spray concentrations of uniconazole $(2,4,8,16$, and $32 \mathrm{mg} \cdot \mathrm{L}^{-1}$ ) linearly reduced plant height of both 'Osaka White' and 'Nagoya Red' ornamental cabbage (Brassica oleracea var. acephala). In their review of Asteraceae responses to PGRs, Latimer et al. (2006) reported that the effective spray rates of uniconazole varied widely from less than $15 \mathrm{mg} \cdot \mathrm{L}^{-1}$ to more than $80 \mathrm{mg} \cdot \mathrm{L}^{-1}$. Although a single spray application of 45 or $60 \mathrm{mg} \cdot \mathrm{L}^{-1}$ uniconazole moderately reduced plant height of 'Burgundy' blanketflower (Latimer et al., 1999), 'Goblin' blanketflower ( $G$. Xgrandiflora) was not responsive (Latimer et al., 2006). Also, although not an objective of our study, it is of interest to mention residual PGR effects and postgreenhouse performance. Latimer et al. (1999) reported that the compaction of uniconazole-treated burgundy blanketflower did not persist through 5 weeks after treatment and did not affect subsequent landscape performance.

As compared with foliar sprays, medium drench applications of uniconazole are sometimes more effective because they are taken up by the roots and xylem transported up the stems to the growing points (Barrett, 2001). Also, it has been suggested that uniconazole drenches may affect cell elongation or division during flower development at a lesser extent than sprays, thus hastening flowering in some species (Barrett, 2001; Starman, 1991). Starman (1991) applied one and two foliar sprays and single drenches of uniconazole to 'Yodel Blue' lisianthus (Eustoma grandiflorum) and found that uniconazole drenching did not delay flowering, whereas foliar spray applications did. Similar to sprays, drenches are species and cultivar specific. Whipker et al. (1995) drenched potted 'Red Pygmy' and 'Golden Emblem' dahlia (Dablia variabilis) with uniconazole and found that only 'Red Pygmy' responded enough to the treatment to be considered marketable.

ETHePhon. Significant rate $x$ spray number interactions occurred for dry weight, visual compactness, and flowering of torch blanketflower plants sprayed with ethephon (Table 2). Ethephon-treated plants had
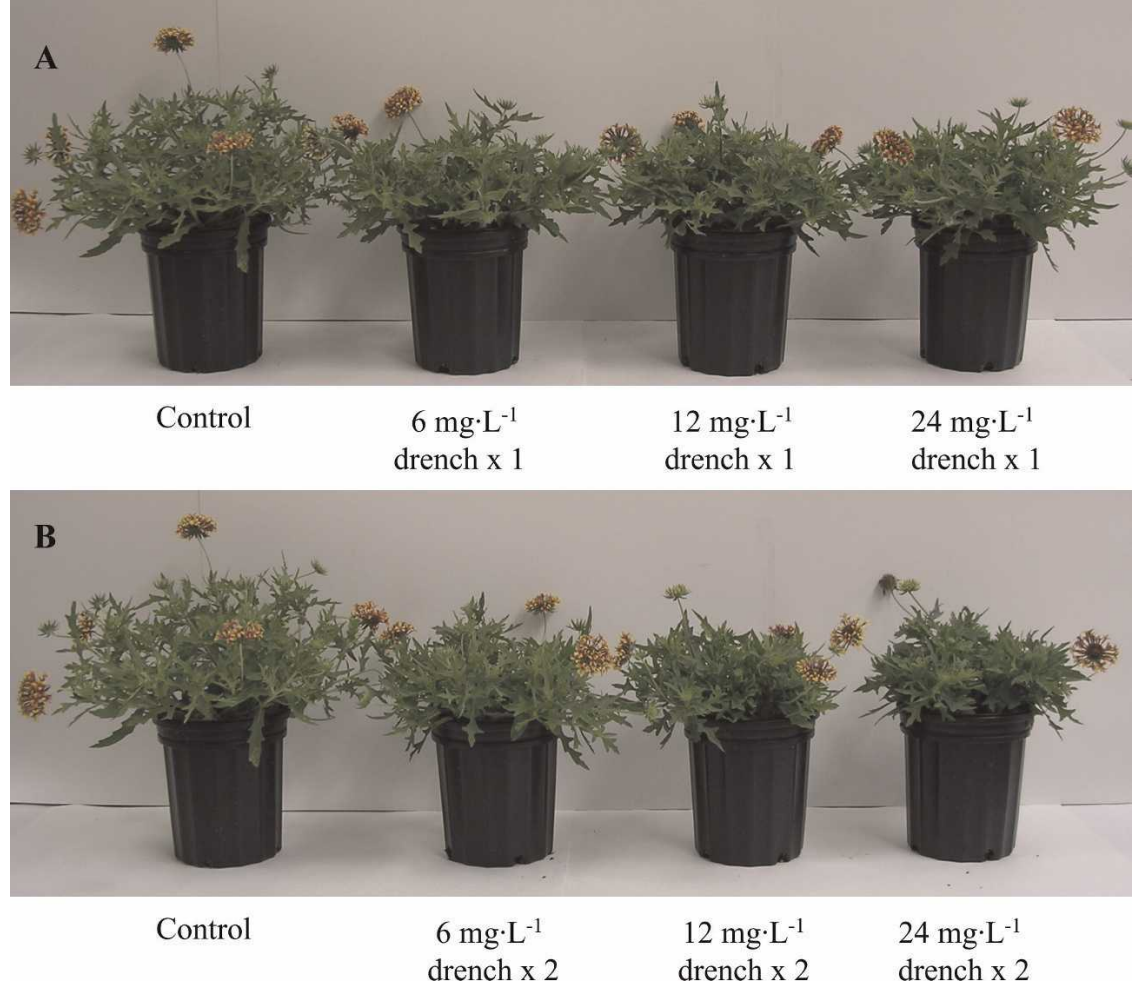

Fig. 1. (A, B) Response of 'Torch Flame' blanketflower drenched with uniconazole at $0,6,12$, or $24 \mathrm{mg} \cdot \mathrm{L}^{-1}$ once $(A)$ or twice $(B) .1 \mathrm{mg} \cdot \mathrm{L}^{-1}=1 \mathrm{ppm}$.

Table 2. Growth index, dry weight, compactness rating, and flower number of 'Torch Flame' blanketflower sprayed with Ethephon $(\mathbf{n}=9)$.

\begin{tabular}{|c|c|c|c|c|c|c|}
\hline$\underline{\text { Rate }\left(\mathrm{mg} \cdot \mathrm{L}^{-1}\right)^{\mathrm{z}}}$ & $\begin{array}{c}\text { Spray } \\
\text { (no.) }\end{array}$ & $\begin{array}{c}\text { Growth } \\
\text { index }^{\mathrm{y}}\end{array}$ & $\begin{array}{l}\text { Dry } \\
\text { wt } \\
(\mathrm{g})^{\mathrm{x}}\end{array}$ & $\begin{array}{l}\text { Compactness } \\
\text { rating } \\
(1-3 \text { scale })^{w}\end{array}$ & $\begin{array}{c}\text { Flowers } \\
\text { at } 3 \text { wk } \\
\text { (no.) }\end{array}$ & $\begin{array}{c}\text { Flowers } \\
\text { at } 4 \text { wk } \\
\text { (no.) } \\
\end{array}$ \\
\hline Control & - & 26.3 & 8.9 & 1.2 & 2.3 & 12.3 \\
\hline 500 & 1 & 22.6 & 6.1 & 2.0 & 0.0 & 7.3 \\
\hline 500 & 2 & 20.8 & 6.5 & 3.0 & 0.0 & 0.0 \\
\hline 1000 & 1 & 22.2 & 7.5 & 3.0 & 0.0 & 0.7 \\
\hline 1000 & 2 & 19.4 & 5.9 & 3.0 & 0.0 & 0.0 \\
\hline \multicolumn{7}{|l|}{ Contrasts } \\
\hline Control vs. others & & $* *$ & ** & ** & ** & ** \\
\hline Rate & & NS & NS & ** & NS & ** \\
\hline Spray no. & & ** & NS & ** & NS & ** \\
\hline Rate vs. spray no. & & NS & * & ** & NS & ** \\
\hline
\end{tabular}

${ }^{\mathrm{z}} \mathrm{l} \mathrm{mg} \cdot \mathrm{L}^{-1}=1 \mathrm{ppm}$.

y Growth index was calculated by the equation (height + average width) $\div 2$.

${ }^{\mathrm{x}} \mathrm{lg}=0.0353 \mathrm{oz}$

wisually assessed on a scale where 1 point is not compact, 2 points is somewhat compact, and 3 points is highly compact.

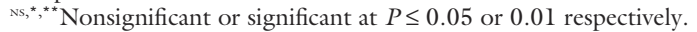

significantly lower growth indices and dry weights, with greater compactness than control plants. Increasing the rate had no effect on growth index or dry weight, but did increase visual compactness. A second spray application had no effect on dry weight or flower number (at 3 weeks), but did reduce growth index and visual compactness. With single- or double-spray applications at 500 and $1000 \mathrm{mg} \cdot \mathrm{L}^{-1}$, plants were 1.7 to 2.5 times more compact than untreated controls, but flowering was delayed. Ethephon reduced torch blanketflower dry weight by as much as $34 \%$ (double application at $1000 \mathrm{mg} \cdot \mathrm{L}^{-1}$ ) compared with untreated controls (Table 2, Fig. 2). In a study using several different container-grown 

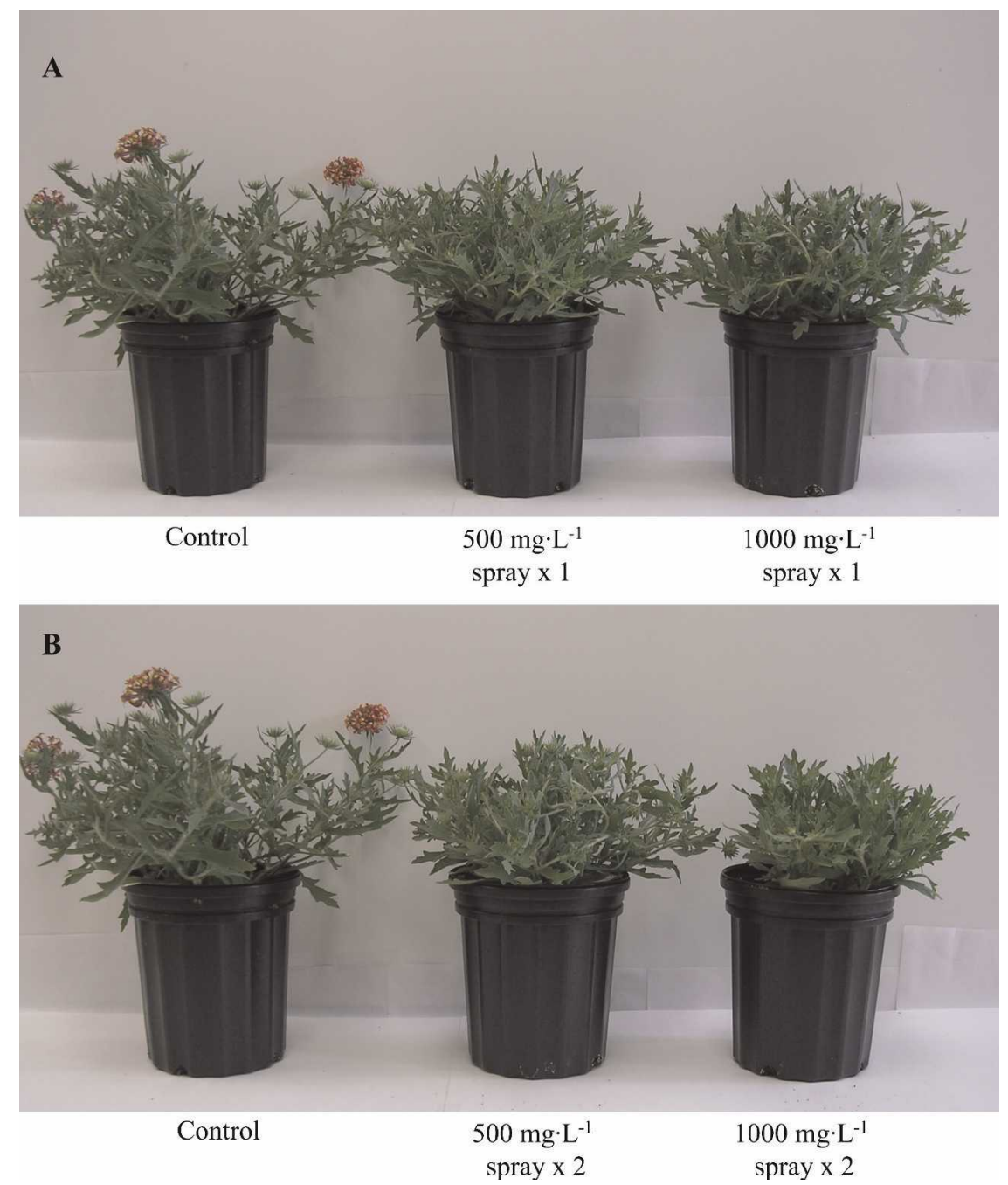

Fig. 2. (A, B) Response of 'Torch Flame' blanketflower sprayed with ethephon at 0,500 , or $1000 \mathrm{mg} \cdot \mathrm{L}^{-1}$ once $(A)$ or twice $(B) .1 \mathrm{mg} \cdot \mathrm{L}^{-1}=1 \mathrm{ppm}$.

perennials, Chamberlayne and Banko (2003) found that single or double applications of $500 \mathrm{mg} \cdot \mathrm{L}^{-1}$ ethephon similarly reduced growth of 'White Swan' coneflower (Echinacea purpurea), but did not control growth of 'Goldsturm' black-eyed susan (Rudbeckia fulgida), 'Autumn Joy' sedum (Sedum $\times)$, or 'Floristan White' gayfeather (Liatris spicata). In addition, Latimer et al. (2001) found that a single application of $500 \mathrm{mg} \cdot \mathrm{L}^{-1}$ ethephon reduced the height of 'Summer Sun' oxeye sunflower (Heliopsis belianthoides) by $11 \%$ to $17 \%$ for 4 to 12 weeks after treatment without delaying flowering. In our study, flowering of ethephon-treated blanketflower was delayed, regardless of application rate or number. All plants did, however, have numerous visible flower buds (Fig. 2), indicating anthesis was near.
The typical concentrations of Ethephon that are recommended for bedding plants range from 250 to 1000 $\mathrm{mg} \cdot \mathrm{L}^{-1}$ (Whipker et al., 2003). Blanketflower may require one or two applications at the lower end of this range to prevent flower delay and excessive persistence. Regardless of application rate or number, ethephon did not affect blanketflower ecotype growth (data not presented).

In summary, blanketflower has varying responses to PGRs. Use of any of the five tested PGRs is not recommended for production of the uncultivated, blanketflower ecotype. The torch blanketflower, however, did respond to drench applications of uniconazole and foliar applications of ethephon. When using uniconazole as a drench for torch blanketflower production, a linear growth response can be achieved with increased rates from 6 to $24 \mathrm{mg} \cdot \mathrm{L}^{-1}$, but a second application is not warranted. Although ethephon reduced growth of torch blanketflower at 500 and $1000 \mathrm{mg} \cdot \mathrm{L}^{-1}$, flowering was delayed. Based only on flowering at 4 weeks after PGR application, ethephon-sprayed plants were considered less marketable compared with uniconazole-drenched plants. It should be noted that our experiments were conducted during mid summer in Florida, therefore recommended rates may need to be lowered for northern growers.

\section{Literature cited}

Barrett, J. 2001. Mechanisms of action, p. 32-47. In: M.L. Gaston (ed.). Tips on regulating growth of floriculture crops. Ball Publishing, Batavia, IL.

Chamberlayne, C.L. and T.J. Banko. 2003. Growth response of containergrown herbaceous perennials to Ethephon, daminozide, paclobutrazol and uniconazole. Southern Nursery Assn. Res. Conf. Proc. 48:267-271.

Danielson, H.H. 2005. Production and performance of Gaillardia cultivars and ecotypes. Dept. of Environ. Hort., Univ. of Florida, Gainesville, FL. MS thesis.

Florida Wildflower Advisory Council. 2004. History. 19 Mar. 2006. <http:// floridawildflowercouncil.org/history. html>.

Gibson, J.L. and B.E. Whipker. 2001. Ornamental cabbage and kale growth responses to daminozide, paclobutrazol, and uniconazole. HortTechnology 11: 226-230

Hammond, H.E., J.G. Norcini, S.B. Wilson, R.K. Schoellhorn, and D.L. Miler. 2007. Growth, flowering, and survival of firewheel (Gaillardia pulchella Foug.) based on seed source and growing location. Native Plants J. 8:25-39.

Hilgers, K.R., C. Haynes, and W.R. Graves. 2005. Chemical height control of containerized seashore mallow. HortTechnology 15:330-332.

Keever, G.J. and J.W. Olive. 1994. Response of 'Prize' azalea to Sumagic applied at several stages of shoot apex development. J. Environ. Hort. 12: 12-15.

Kim, S., A.A. De Hertogh, and P.V. Nelson. 1999. Effects of plant growth regulators applied as sprays or media drenches on forcing of Dutch-grown bleeding heart as a flowering potted plant. HortTechnology 9:629-633. 


\section{Research Reports}

Krug, B.A., B.E. Whipker, I. McCall, and J.M. Dole. 2006. Narcissus response to plant growth regulators. HortTechnology 16:129-132.

Latimer, J.G., T.J. Banko, and V. Groover. 2001. Using PGRs to hold containerized perennials in the nursery. Southern Nursery Assn. Res. Conf. Proc. $46: 336-338$

Latimer, J.G., P. Lewis, and P.A. Thomas. 1999. Plant growth regulator effects on height and landscape performance of perennial bedding plants. Acta Hort. 504:83-91.

Latimer, J.G., H. Scoggins, and V. Groover. 2006. PGRs on perennial plants: Examples from the Asteraceae family. Ohio Florist Assn. Bul. 895: 9-12.
Norcini, J.G. and J.H. Aldrich. 2004. Establishment of native wildflower plantings by seed. 19 Mar. 2006. <http:// edis.ifas.ufl.edu/ep227>.

Rademacher, W. 1991. Biochemical effects of plant growth retardants, $\mathrm{p}$. 169-191. In: H.W. Gausman (ed.). Plant biochemical regulators. Ice Marcel Dekker, New York.

Schoellhorn, R. 2004. Gaillardia. Greenhouse Product News 14:14-16.

Starman, T.W. 1991. Lisianthus growth and flowering responses to uniconazole. HortScience 26:150-152.

Thomas, P.A., J.G. Latimer, and S.A. Baden. 1998. Greenhouse and landscape evaluation of perennial bedding plants treated with three plant growth regula- tors. Southern Nursery Assn. Res. Conf. Proc. 43:286-290.

U.S. Department of Agriculture. 2006. The PLANTS database. 7 Jan. 2007. $<$ http://plants.usda.gov>.

Whipker, B.E., R.T. Eddy, and P.A. Hammer. 1995. Chemical growth retardant application to tuberous-rooted dahlias. HortScience 30:1007-1008.

Whipker, B.E., J.L. Gibson, T.J. Cavins, I. McCall, and P. Konjoian. 2003. Growth regulators, p. 85-12. In: D. Hamrick (ed.). Ball redbook crop production vol. 2. Ball Publishing, Batavia, IL.

Wunderlin, R.P. and B.F. Hansen. 2004. Atlas of Florida vascular plants. 7 Jan. 2007. <www.plantatlas.usf.edu>. 